the acridoidea of the Omsk region, he went on to study their ecology. In later years he divided his interest between the taxonomy and ecology of orthopteroid insects.

In 1927 Bei-Bienko moved to Leningrad, where he was to spend the rest of his life, and began work in the Zoological Museum of the Academy of Sciences of the USSR. Although always retaining a close connexion with this museum, he moved in 1929 to the Plant Protection Institute of the USSR and in 1938 to the Leningrad Agricultural Institute, where he held the chair of general entomology until his illness last year. While working in Leningrad Bei-Bienko published several major works on the systematics of the dictyoptera, dermaptera, tettigonioidea and acridoidea of the USSR, and at the same time produced many papers on the applied entomology and ecology of these groups. He took part in many expeditions, both within the USSR and to other Asiatic countries, and this resulted in the publication of a number of faunistic studies.

During the siege of Leningrad in the Second World War, Bei-Bienko took an active part in defending the city, and it was only when he became completely exhausted that he was evacuated to Perm, where he remained until the end of the war.

Professor Bei-Bienko will be remembered not only for his substantial contributions to science, but also for the warmth and good humour of his personality. He was a man of remarkable energy and remained fully active in his scientific work until the year of his death.

\section{Mr Michael Graham}

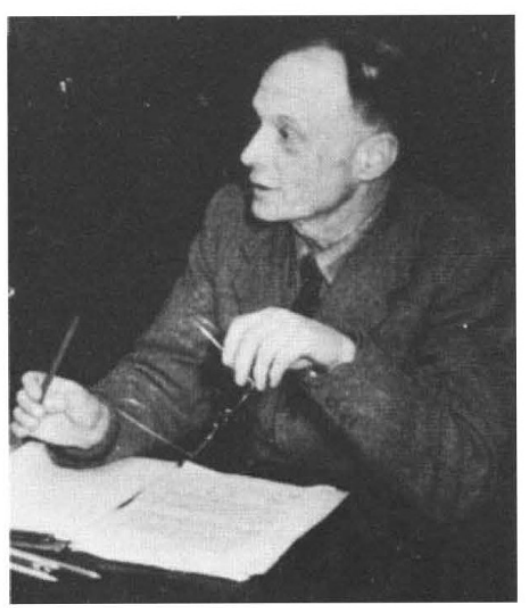

Michael Graham, a former Director of Fishery Research in the Ministry of Agriculture, Fisheries and Food, died on January 1, aged 73.

He will be remembered firstly as a distinguished marine scientist who was largely responsible for the development of British fishery research after the Second World War to a position of world renown, and secondly, as a man who appreciated the importance of ecological studies and the need for conservation of natural resources many years before such ideas attained their present importance and, what is more, took practical steps to translate his ideas into action. But to those who worked with him he will also be remembered as a man of deep sympathy and understanding. This is clear from his books and it dominated his personal relations. Never could there have been a better mentor to lead the young biologist through the intricacies of fisheries research and its applications.

After service in the Royal Navy during the First World War Michael Graham went to Cambridge to read Natural History and joined the staff of the Fisheries Laboratory, Lowestoft, in 1920. At first he worked mainly on the biology of the North Sea cod, and in particular studied its life history and fluctuations in the size of the stock.

Between 1927 and 1928 these studies were interrupted by a period of work in East Africa to carry out fishing survey of Victoria Nyanza. This was concerned with the study of the distribution of the important food fish, Tilapia esculenta, and the danger of its being over-fished, and it resulted in the formulation of a series of recommendations to the appropriate governments. This was a period of fruitful collaboration with E. B. Worthington and the expedition started a movement whereby fishery science, which had been developed in the seas, became applied to large lakes, especially those in the tropics. The study of Victoria Nyanza stimulated other surveys and from them has emerged, over the years, a large and flourishing fishing industry as well as much research which has revealed some of the fundamental processes of biological production.

In both his North Sea and Victoria Nyanza studies Graham had been concerned with the problem of rational fishing, and in the 1930s he became concerned with the general problem of the dynamics of exploited fish populations. In this he followed the lead given by his director, E. S. Russell. $\mathrm{He}$ assumed that the growth of a fish population took the form of the logistic curve observed for other populations and from this concluded that the most effective level of fishing is that which maintains the population at an abundance equal to about one half that of the virgin stock. Outside the laboratory he found time during this period to study, experiment in and write about soil and grassland management.

After service in the RAF during the Second World War Michael Graham was appointed Director of Fishery
Research and was responsible for the Ministry's fishery research programme until he retired in 1958 . This period was particularly noteworthy for the impetus which he gave to the mathematical studies of fish populations by recruiting to the Lowestoft laboratory and encouraging the work of men like Beverton, Holt and Gulland. $\mathrm{He}$ also played a prominent part in obtaining intergovernmental agreement concerning fish conservation in the North Sea and elsewhere. Other milestones during his directorship were the establishment of the Ministry's fisheries radiobiological laboratory at Lowestoft and its shellfish research laboratory at Burnham-on-Crouch, and the development of a comprehensive research programme in distant waters, especially the Barents Sea, based on cruises carried out in all seasons of the year by the research vessel Ernest Holt.

After retirement he carried out highly successful pioneer work on the reclamation of slag heaps in Lancashire and his experiments showed that they could be "greened over" at very little cost. $\mathrm{He}$ also became a special lecturer in biology at Salford University from 1966 to 1971 and delighted in expressing in lecture and book form the importance of ecology and in illustrating his theme with practical examples culled from various parts of his own career.

\section{Announcements}

\section{University News}

Professor E. J. H. Corner, University of Cambridge, has been appointed Royal Society Leverhulme visiting professor to the National Biological Institute, Bogor, Indonesia, for a period of 7 months.

Dr V. Dubowitz, University of Sheffield, has been appointed to the chair of paediatrics at the Institute of Child Health, attached to the Royal Postgraduate Medical School, University of London.

Dr C. J. Stairmand has been appointed to an industrial chair in the Department of Chemical Engineering, Loughborough University of Technology.

\section{Appointments}

Professor R. E. O. Williams has been appointed director of the Public Health Laboratory Service in succession to Sir James Howie, who will retire in September 1973.

\section{Miscellaneous}

The Institution of Mechanical Engineers will award annually a senior James Clayton fellowship, for project or study programmes in specific areas of mechanical 